\title{
Determinants and Consequences of Intellectual Capital Efficiency in the U.S. Banking Industry
}

\author{
Justin Y. Jin*, Wenting Wang \\ DeGroote School of Business, McMaster University, Hamilton, Ontario, Canada \\ Email: *jinjus@mcmaster.ca
}

How to cite this paper: Jin, J. Y., \& Wang, W. T. (2020). Determinants and Consequences of Intellectual Capital Efficiency in the U.S. Banking Industry. Theoretical Economics Letters, 10, 384-408. https://doi.org/10.4236/tel.2020.102026

Received: March 7, 2020

Accepted: April 26, 2020

Published: April 29, 2020

Copyright (C) 2020 by author(s) and Scientific Research Publishing Inc. This work is licensed under the Creative Commons Attribution International License (CC BY 4.0).

http://creativecommons.org/licenses/by/4.0/

\begin{abstract}
This study investigates the determinants and consequences of intellectual capital efficiency in the U.S. banking industry. We find that banks' individual institutional memory of bad times reduces their intellectual capital efficiency. We also find that intellectual capital efficiency restricts banks' risk-taking behaviors and enhances their accounting conservatism. Finally, we find that intellectual capital efficiency helps banks attract more wholesale funding deposits. In addition, we test the impact of three components of intellectual capital efficiency on bank accounting conservatism, and find that both human capital efficiency and relational capital efficiency significantly impact on bank accounting conservatism.
\end{abstract}

\section{Keywords}

Banks, Intellectual Capital Efficiency, Human Capital Efficiency, Relational Capital Efficiency, Structural Capital Efficiency, Organizational Memory, Risk Taking, Accounting Conservatism, Funding Structure

\section{Introduction}

Intellectual capital is a popular research topic in the literature on organizational behavior. Traditional financial reports have ignored the intangible values of intellectual capital. Gogan et al. (2016) document that intellectual capital efficiency can create competitive advantages for business organizations. Abdulaali (2008) argues that intellectual capital is important for organizations that want a timely and efficient reaction to changes in the markets. However, most studies of intellectual capital focus on the causal connection to organizational performance. The literature to date has been limited to nonfinancial industries. After identifying the research gaps in the examination of intellectual capital, we analyze and 
reveal the causes and effects of intellectual capital efficiency in the banking industry.

Commercial banks have a central role in the financial system and are essential to a society's macroeconomy. They attract retail savings and make loans. Tan (2016) points out that banks are the most influential component of the financial system. Belias (2014) documents the important and complex roles of banks. He argues that banks regulate the liquidity of an economy, set interest rates, affect the capital market, manage funds and securities, and hedge risks in the capital market. Considering the importance of commercial banks in controlling the capital flow and maintaining economic stability, we use this study of the banking sector to confirm the unique function of intellectual capital in banks.

We begin by examining the determinants of intellectual capital efficiency. Based on organizational learning theory, we focus on banks' organizational memory. We examine the effects of individual banks' bad experience of undercapitalization, and their observation of bad times (i.e., financial meltdown) at a macroeconomic level. We argue that if banks survive their own undercapitalization crisis, bank managers might become concerned about their future. When bank managers face new investment projects using intellectual capital that are hard to measure using monetary values, they may postpone those projects. However, once banks survive a macroeconomic shock, the ensuing overconfidence and mental shocks might be offsetting. Following Meles et al. (2016), we use the Value-Added Intellectual Coefficient (VAIC) method as the proxy for intellectual capital efficiency. An indicator variable for undercapitalization status is used to capture bank-specific memory of bad times, and the average proportion of banks that failed in each state each year is used to capture banks' memory of macroeconomic shocks (Bouwman \& Malmendier, 2015). We find evidence to support the view that there is a significantly negative relationship between intellectual capital efficiency and bank-specific memories of bad times.

After identifying the causal connection between banks' institutional memory and their intellectual capital efficiency, we move to the next node in the logic chain and explore the causal effect of intellectual capital efficiency on banks' actions. Excessive risk-taking in the banking sector is seen as a principal contributor to the 2007-2009 economic crisis (Bushman \& Williams, 2012). In alignment with the reasoning presented in Garrett et al. (2014), intellectual capital limits managers' opportunistic behaviors. This reasoning is clearer when we analyze the individual human, relational, and organizational subcomponents of intellectual capital. By calculating the negative values of the $\mathrm{Z}$ score and the ratio of loan loss provisions to nonperforming loans, we construct the measure of banks' risk taking and conservatism following previous studies (e.g., Kanagaretnam et al., 2011; Betty \& Liao, 2011). Our study supports the hypothesis that intellectual capital efficiency can constrain banks' risk taking and improve accounting conservatism.

Our final baseline tests confirm whether intellectual capital can affect banks' 
funding structure. Considering the deposit insurance provided by the Federal Deposit Insurance Corporation (FDIC) to protect retail depositors, we argue that any enhancement in intellectual capital efficiency enables banks to attract more wholesale funding by signaling their strength to the lending markets. To test our prediction, we calculate the retail deposit ratio as core deposits (deposits to checking and savings accounts) divided by total assets, and the wholesale deposit ratio as 1 minus the retail deposit ratio. We test the relationship between the retail deposit ratio and intellectual capital efficiency, and find that enhancement in intellectual capital efficiency enables banks to attract more wholesale deposits and fewer retail deposits.

In our supplementary tests, we detect the distinct effect of each of the three subcomponents of intellectual capital efficiency. We also do a subsample test to investigate whether public and private banks have different levels of sensitivity to intellectual capital efficiency. The results of the supplementary tests align with our hypotheses and confirm the baseline results.

Our paper makes several contributions. The results shed light on the role of intellectual capital efficiency in affecting banks' risk taking, accounting conservatism, and funding structure. The paper also identifies institutional memory as one cause of intellectual capital efficiency. In addition, our study provides insights into the importance of intellectual capital efficiency that restricts banks' risk-taking behaviors, enhances their accounting conservatism, and increases wholesale deposits. The findings in this paper form a comprehensive picture of intellectual capital efficiency that will be useful to policymakers, management, and academia.

The rest of the paper is organized as follows. In Section 2, we review the literature and formulate our hypotheses. In Section 3, we present the research design and describe our sample. In Section 4, we discuss the empirical results. In Section 5, we document our conclusions and contributions.

\section{Literature Review and Hypotheses Development}

Based on the concept and the processes of knowledge management, Nahapiet and Ghoshal (1998) define intellectual capital as "the knowledge and knowing capability of a social collectivity, such as an organization, intellectual community, or professional practice." According to Abdulaali (2008), intellectual capital can bring future benefits to a business organization by enabling it to adjust faster to external environmental changes. Haris et al. (2019) report that besides the values created by balance sheet items, the off-balance sheet items such as intellectual capital can contribute to companies' value. Wang (2016) argues that intellectual capital dominates the creation of value for a company. Intellectual capital is considered to have intangible value for an organization and there has been a call for these intangible assets to be evaluated and managed as carefully as tangible assets are (Mojtahedi, 2013). Compared with the strict focus of the term intellectual capital on value, the term intellectual capital efficiency places more 
emphasis on the value added to the organization ${ }^{1}$.

Based on prior studies (e.g. Yang \& Lin, 2009; Meles et al., 2016), there are three subcomponents of intellectual capital: human, relational and organizational. Human capital refers to the increased value of the employees' skills, productivity, and efficiency through training programs. Structural capital refers to the nonhuman intangible assets such as patents, databases, cultural climate, and the organizational philosophy that provides a supportive infrastructure to the functioning of human capital (Yang \& Lin 2009; Daum 2003). Daum (2003) defines relational capital as a critical component in the relationship between a business organization and its external stakeholders and related parties. Two good examples of relational capital are social trust and experience.

Mojtahedi (2013) and Meles et al. (2016) state that intellectual capital efficiency can be split into three sub-aggregates: Human Capital Efficiency (HCE), Relationship Capital Efficiency (RCE) and Structural Capital Efficiency (SCE) ${ }^{2}$. Previous studies have examined the effects of each subcomponent on firms' financial performance (e.g., Wang, 2016; Abdulaali, 2018).

The studies of intellectual capital focus on the relationship between intellectual capital and firm performance. Yen et al. (2019) explore the impact of intellectual capital on the banking industry's financial performance. In their summary of the literature, they find that most of the papers adopt ROA and ROE as the performance metrics. Buy-and-hold returns can also be used to measure bank performance (e.g., Aebi, Sabato, \& Schmid, 2012).

Wang (2016) tests each component of intellectual capital by developing an intellectual-capital-oriented framework and finds that all subcomponents have significant and positive effects on an organization's financial performance. Kariuki and Kiambati (2017) detect the moderating effect of corporate culture on the relationship between intellectual capital and financial performance (ROA, ROE, and dividend yield) using survey data collected in Nairobi, Kenya. Jordão and Almeida (2017) explore the effects of intellectual capital on long-term firm performance (i.e., financial sustainability). Sullivan and Sullivan (2000) point out that intellectual capital can leverage firms' profitability. Using banking samples from Pakistan, Haris et al. (2019) document linear and nonlinear relationships between intellectual capital and firm profitability. Overall, the power of intellectual capital in driving financial performance and firms' profitability is found in both nonfinancial institutions and financial institutions.

Prior studies of earnings quality in the intellectual capital context were conducted on nonfinancial institutions. Darabi et al. (2012) and Mojtahedi (2013) use discretional accruals as the inverse proxy of earnings quality in nonfinancial firms based on the Modified Jones Model (1991). Both papers find a positive and

${ }^{1}$ Kujansivu and Lönnqvist (2007) show the relationship between the value of intellectual capital and intellectual capital efficiency varies across different industries. In our context, for simplicity, we do not strictly distinguish intellectual capital and intellectual capital efficiency.

${ }^{2}$ Meles et al. (2016) uses capital employed efficiency (CEE), which is equivalent to relational capital efficiency (RCE). 
remarkable relationship between intellectual capital and earnings quality. Mojtahedi (2013) examines the distinct effects of the three subcomponents of intellectual capital on firms' earnings quality and tests the moderating effects of two variables-firm size and debt to equity ratio-in these relationships.

Putnam (1995) defines social capital as "the features of social life-networks, norms and trust that enable participants to act together more effectively to pursue shared objectives". Putnam (1995) and Nahapiet \& Ghoshal (1998) categorize three attributes of social capital: structural, relational, and cognitive. The structural dimension contains the networks of all relations among parties in a community. The relational attribute illustrates the interpersonal relationships and interactions. Both the structural and the relational dimensions can be matched with structural and relational capital in the subcomponents of intellectual capital. The major difference between the paired components is that the latter falls within the confines of a business organization while the former is relegated to the outside environment.

Previous studies have investigated the role of intellectual capital in the performance in nonfinancial firms. It is surprising that the whole mechanism of intellectual capital in the banking industry is still a black box. Generally speaking, commercial banks are responsible for attracting deposits and offering loans and financial services to the public. Considering the essential function of commercial banks as the control sector for capital flow in society and their irreplaceable role in maintaining the stability of the economy and financial system, we investigate how intellectual capital works in the banking industry.

We focus on some exogenous factors involved in the interaction between the organization and the environment when we explore the determinants of banks' intellectual capital efficiency. We first study the banks' organizational memory. Organizational learning theory is defined as learning "by encoding inferences from history into routines that guide behavior" (Levitt \& March, 1988). Levitt and March (1988) argue that organizations can generate conceptual paradigms by learning from past direct or indirect experiences. Bouwman and Malmendier (2015) investigate the effect of banks' organizational memory on their capital structure and risk-taking behavior. Liu (2017) has shown that past macroeconomic and bank-specific experiences lead to greater accounting conservatism.

Following organizational learning theory, we investigate whether banks' organizational memory affects their intellectual capital efficiency. We define banks' organizational memory as their historical experiences in bad times, following Liu (2017) and Bouwman and Malmendier (2015). Banks' historical experiences in bad times can be categorized as micro-historical (i.e. bank-specific) and macro-historical (i.e. economy-wide). We then generate two hypotheses for each type of organizational memory.

The first hypothesis pertains to the relationship between bank-specific bad experiences and intellectual capital efficiency. We argue that banks tend to generate pessimism after they have survived a bad financial situation. They then be- 
come more sensitive to management discretionary judgments. The findings that banks would become more conservative by increasing the recognition of expected losses (i.e., Liu, 2017) support this argument. Following the same reasoning, we expect to see that banks tend to rely on "hard" rules and policies rather than the "soft" organizational culture. Such an experience in capital-constrained periods gives banks an incentive to set up more visible and controllable policies and economic contracts. Correspondingly, banks would decrease investment in intangible and unquantifiable assets such as innovation programs and job training programs, which are critical components of intellectual capital. Therefore, we expect to find a decrease in intellectual capital efficiency after bank-specific shocks. We generate our first hypothesis:

H1: Current intellectual capital efficiency of banks is negatively associated with past bank-specific experience of bad times.

The second hypothesis is about the effect of banks' experience in a macroeconomic meltdown on their current intellectual capital efficiency. On the one hand, consistent with the hypothesis generated for banks' specific memory of bad times, we argue that banks are more likely to refine their "hard" rules and avoid reliance on investment in intellectual capital. On the other hand, we have to be aware of the difference between individual banks' bad times and the macro environment. So when the banks experience only micro-level shocks, they are more likely to overstate their ability to survive the hard economy and be less sensitive to earnings management. Bouwman and Malmendier (2015) fail to find a significant positive effect of macroeconomic shocks on banks' lending and capitalization behaviors. Liu (2017) documents that macroeconomic shocks do not induce more conservative accounting behaviors. Taken together, we expect to find insignificant changes in intellectual capital efficiency after banks experience macroeconomic bad times. Our second hypothesis is as follows:

H2: Current intellectual capital efficiency of banks is not associated with past organizational memories of bad times at the macro level.

Belias (2014) documents that risk management is one of the most challenging issues faced by banks. In addition, banks are more opaque than other industrial firms, which leads to greater opportunities for risk-taking behaviors (Kanagaretnam et al., 2013). Aebi, Sabato and Schmid (2012) argue that risk management of financial institutions is particularly monitored by regulators.

A fruitful body of research has examined the determinants of banks' risk-taking behaviors. We categorize the determinants of risk-taking behaviors as follows. The first type consists of formal factors such as external governance by regulators. For example, Jin et al. (2013) explore the relationship between the Federal Deposit Insurance Corporation Improvement Act (FDICIA), internal control and banks' risk-taking behaviors. The second type consists of informal factors such as cultural climate. These factors can be classified as from the organizations' perspectives.

Bushman et al. (2015) investigate the influence of bank CEOs' personal char- 
acteristics on banks' risk culture. Some papers discuss corporate culture in the banking industry and focus on risk awareness, attitudes to risks, and risk management (e.g., Thakor, 2015; Financial Stability Board, 2014). Li et al. (2013) borrow the concepts of individual autonomy and self-enhancement from the psychological research and show that national culture can affect managerial risk-taking. Aebi, Sabato and Schmid (2012) explore the effects of a risk management mechanism, the reporting targets of the chief risk officer (CRO), on firm performance. Jin et al. (2017) demonstrate that social capital has a negative relationship with banks' abnormal risk-taking behaviors under normal scenarios. Accordingly, social capital represents the external informal determinants, while CEOs' characteristics represent the internal informal determinants.

In alignment with the literature, we predict that intellectual capital is a good internal informal predictor of banks' risk-taking behaviors. Relational capital, as a subcomponent of intellectual capital, comprises relationships and networks that interact with their environments. Still, Huhtamäki and Russell (2013) show the linkage between relational capital and social capital, and the distinct role of each one. In other words, relational capital addresses the relationship between a firm and its stakeholders and customers; social capital is the totality of the relationship in a society or a community. Therefore, social capital is arguably an indicator of external "intangible" determinants of banks' behaviors, and conversely, intellectual capital is categorized as an indicator of internal unquantifiable determinants of banks' behaviors.

Nahapiet and Ghoshal (1998) argue that social capital promotes the development of new intellectual capital. They use the theory of organizational advantage to explain knowledge creation and sharing behaviors. Like the mechanism through which social capital affects banks' risk taking, intellectual capital can constrain managers' self-serving, opportunistic and unethical behaviors, and thus can curtail excessive risk taking (e.g., Garrett et al., 2014; Jin et al., 2017). Strong human capital, structural capital, and relational capital can give a bank the ability to compete with other banks in attracting high-quality and trustworthy borrowers. Such banks tend to experience fewer capital constraints and stressful situations. Thus, banks value and benefit from mutual trust and reputational networks with their customers and stakeholders, and have less incentive to take abnormal risks.

Furthermore, Nahapiet and Ghoshal (1998) find evidence that social capital facilitates the creation of intellectual capital in a firm. Consequently, we argue that intellectual capital can be a channel or mediator for the causal relationship between social capital and banks' risk-taking behaviors. The social norms proxied by social capital are transmitted to banks' internal intellectual capital, and then can limit banks' abnormal risk-taking behaviors. We therefore generate the following hypothesis:

H3: Improvements in intellectual capital efficiency can limit banks' risk-taking behaviors. 
Next, we study the correlation between intellectual capital efficiency and banks' accounting conservatism. Accounting conservatism refers to the timelier recognition of earnings decreases. Basu (1997) describes accounting conservatism as "resulting in earnings reflecting bad news more quickly than good news". Givoly et al. (2010) characterize accounting conservatism as asymmetric timeliness in recognizing losses as opposed to gains. Kravet (2014) finds a negative association between accounting conservatism and risky managerial investments. Mechelli and Cimini (2017) state that risk culture has a negative relationship with banks' conservative accounting. Kanagaretnam et al. (2013) reveal opposite directions of the influences of national culture on risk taking and accounting conservatism. Lara et al. (2016) argue that accounting conservatism can enhance investment efficiency by promoting investment in the firms facing underinvestment and by constraining overinvestment. Therefore, investigating the reaction of accounting conservatism to intellectual capital efficiency has important practical and theoretical implications.

In our context, intellectual capital efficiency is predicted to be a channel that can affect variations in accounting conservatism among banks. Following hypothesis $\mathrm{H} 3$, we predict that improvements in intellectual capital efficiency can limit banks' risk-taking behaviors. The reduction of risk-taking behaviors of banks partially recognizes that the banks do not have strong incentives to manage earnings and engage in aggressive financial reporting. If high intellectual capital efficiency can reduce banks' risk-taking activities, then it can limit banks' overstatement of revenues/assets and enhance their conservative accounting policies. We expect to observe a positive relationship between intellectual capital efficiency and accounting conservatism. We generate the following hypothesis:

H4: Improvements in intellectual capital efficiency can enhance banks' accounting conservatism.

Another factor that is unique to the banking industry and important to banks' financial performance is its funding structure. Retail and wholesale deposits comprise a bank's funding sources. In our study, retail funds are the core deposits for checking and savings accounts. Wholesale deposits include federal funds, repo agreements, foreign deposits, brokered deposits, and other short-term liabilities. The percentage of wholesale funding in banks' funding structure was a predictor of solvency problems during the 2007-2009 financial meltdown (Truno et al. 2017). Truno et al. (2017) show that compared with wholesale funding, retail deposits are more stable because of FDIC deposit insurance. In the U.S., state banks are supervised by both federal (i.e., FDIC and the Federal Reserve System) and state regulators (Nicoletti, 2018). If depositors suspect that their funds are unsafe, they may take action such as withdrawing their money. To eliminate the risk of bank runs, the FDIC provided $\$ 100,000$ of deposit insurance for each depositor before 2008 and \$250,000 afterwards. Most retail depositors are insured by the FDIC. We therefore predict that wholesale funding providers are more sensitive to the "soft" information or climate in the fund-receiving banks. More 
precisely, based on signaling theory, the intangible intellectual capital system in a bank is a good channel to provide more information that signals the bank's trustworthiness to funding providers. We argue that intellectual capital can enhance banks' investment efficiency by promoting wholesale deposits.

H5: Improvements in intellectual capital efficiency enable banks to attract more wholesale deposits.

We use OLS regressions to test the five hypotheses described above. In testing the first and second hypotheses, we use the value added intellectual capital efficiency (VAIC) as the dependent variable and the undercapitalization (UNCAP) and the average proportion of banks failed in the state-year (FNMR) as the independent variables to run the OLS regressions. In testing the third, fourth, and fifth hypotheses, we use the negative value of ZSCORE (ZSCORENEG), the delay in expected loss recognition (ALLP), and the wholesale funds scaled by total assets (WD) as the dependent variables, and use the value added intellectual capital efficiency (VAIC) as the independent variable to run the OLS regressions.

\section{Sample Selection and Research Design}

In the U.S., all commercial banks are required to file the Report of Condition and Income (or call report). The quarterly institution-level financial data are collected from the call reports on the Federal Reserve Bank of Chicago website (https://www.chicagofed.org/banking/financial-institution-reports/commercialbank-data). The sample consists of 6312 U.S. commercial banks with 106,272 quarterly observations for the period between 2000 and 2017. The original sample has 162,527 quarterly observations before we delete the observations that have no accounting data.

Meles et al. (2016) employ the Value-Added Intellectual Coefficient (VAIC) to measure the value added to a business organization by intellectual capital. This method can realize the measurement of the efficiency of intellectual capital. In our context, we focus on intellectual capital efficiency rather than the value of intellectual capital. According to our definitions, the proxy for intellectual capital efficiency (VAIC) contains three sub-aggregates (HCE, RCE, and SCE). Before we calculate the VAIC and its subcomponents, we define three critical variables. Value added (VA) is the difference between a firm's total output and its total input. It is the profit before income tax and extraordinary items and other adjustments plus the total salaries and employee benefits. HC consists of the human capital expenses that are considered the investment of an organization and can be captured by the total salary and wages expenses. CA (i.e., capital employed) is the book value of both the physical and financial net assets in an organization. SC is structural capital. VAIC and its three ingredients can be calculated by the following equations:

$$
\begin{gathered}
\text { VAIC }=\text { HCE }+ \text { RCE }+ \text { SCE } \\
\text { HCE }=\frac{\text { VA }}{\mathrm{HC}}
\end{gathered}
$$




$$
\begin{gathered}
\mathrm{RCE}=\frac{\mathrm{VA}}{\mathrm{CA}} \\
\mathrm{SCE}=\frac{\mathrm{SC}}{\mathrm{VA}} \\
\mathrm{SC}=\mathrm{VA}-\mathrm{HC}
\end{gathered}
$$

In terms of the measurement of banks' organizational memory, we follow Bouwman and Malmendier (2015) to construct the variables to proxy for the bank-specific bad times and macroeconomic shocks separately. Banks are considered to be experiencing an individual bad time when they are undercapitalized. Therefore, the first variable is an indicator variable of undercapitalized status (UNCAP) for a bank, which is 1 if the tier 1 risk-based capital ratio is under $4 \%$ (before 1990) or the total risk-based ratio is under $8 \%$ (after 1990) (FDIC, 1992; Dahl and Spivey, 1995), and 0 otherwise. To capture the experience of the macroeconomic crisis, we construct the second proxy, FNMR, as the average proportion of banks that failed in the state in a given year.

Following Kanagaretnam et al. (2011), we choose Z score (ZSCORE) as the measure of risk taking to test whether higher levels of intellectual capital efficiency could induce banks to adopt greater risk-taking behaviors. Z score can also be interpreted as financial fragility, the vulnerability of a firm's financial system to shocks in bad times. $\mathrm{Z}$ score is calculated as the sum of return on assets and capital asset ratio divided by the standard deviation of return on assets. Since Z score proposes a given bank's resistance to insolvency (Roy, 1952; Li et al., 2017), we have to convert the original $Z$ scores to their negative values (ZSCORENEG) to make the direction of the coefficient for our interested variable consistent with our hypothesis.

We employ the delay in expected loss recognition (ALLP) as a proxy for a bank's accounting conservatism. The degree of accounting conservatism is the timeliness of recognition of credit losses. Like Beatty and Liao (2011), we use the ratio of the allowance of loan loss provisions divided by nonperforming loans of a bank in a given year as the metric to capture the bank-level delay in expected loss recognition. The higher the ratio of the allowance of loan loss provisions divided by nonperforming loans, the more conservative the bank's accounting policy.

Consistent with Meles et al. (2016) and Bouwman and Malmendier (2015), we estimate the following regression models to complete our data analysis. Equations (1)-(5) are used to test the six hypotheses on the determinants and consequences of intellectual capital efficiency in the banking industry with the standard error clustered at the county level. All continuous variables are winsorized at the 1st and 99th percentiles to mitigate the effect of outlying observations.

$$
\begin{aligned}
\text { VAIC }= & \beta_{0}+\beta_{1} \text { UNCAP }+\beta_{2} \text { GDPPC }+\beta_{3} \text { UNEMPLOYMENT } \\
& +\beta_{4} \text { POPULATION }+\beta_{5} \text { SIZE }+ \text { YEAR_FIXED_EFFECTS }+\varepsilon \\
\text { VAIC }= & \beta_{0}+\beta_{1} \text { FNMR }+\beta_{2} \text { GDPPC }+\beta_{3} \text { UNEMPLOYMENT } \\
& +\beta_{4} \text { POPULATION }+\beta_{5} \text { SIZE }+ \text { YEAR_FIXED_EFFECTS }+\varepsilon
\end{aligned}
$$




$$
\begin{aligned}
\text { ZSCORENEG }= & \beta_{0}+\beta_{1} \mathrm{VAIC}+\beta_{2} \text { TIER } 1+\beta_{3} \mathrm{ROA}+\beta_{4} \mathrm{LIQUIDITY} \\
& +\beta_{5} \mathrm{NPL}+\beta_{6} \mathrm{CI}+\beta_{7} \frac{\text { LOANS }}{\mathrm{DEP}}+\beta_{8} \mathrm{GDPPC} \\
& +\beta_{9} \mathrm{UNEMPLOYMENT}+\beta_{10} \mathrm{POPULATION} \\
& +\beta_{11} \mathrm{SIZE}+\mathrm{YEAR} \text { FIXED_EFFECTS }+\varepsilon \\
\mathrm{ALLP}= & \beta_{0}+\beta_{1} \mathrm{VAIC}+\beta_{2} \mathrm{TIER} 1+\beta_{3} \mathrm{ROA}+\beta_{4} \mathrm{LIQUIDITY}+\beta_{5} \mathrm{NPL} \\
& +\beta_{6} \mathrm{CI}+\beta_{7} \frac{\mathrm{LOANS}}{\mathrm{DEP}}+\beta_{8} \mathrm{GDPPC}+\beta_{9} \mathrm{UNEMPLOYMENT} \\
& +\beta_{10} \mathrm{POPULATION}+\beta_{11} \mathrm{SIZE}+\text { YEAR_FIXED_EFFECTS }+\varepsilon \\
\mathrm{WD}= & \beta_{0}+\beta_{1} \mathrm{VAIC}+\beta_{2} \mathrm{TIER} 1+\beta_{3} \mathrm{ROA}+\beta_{4} \mathrm{LIQUIDITY}+\beta_{5} \mathrm{NPL} \\
+ & \beta_{6} \mathrm{CI}+\beta_{7} \frac{\mathrm{LOANS}}{\mathrm{DEP}}+\beta_{8} \mathrm{GDPPC}+\beta_{9} \mathrm{UNEMPLOYMENT} \\
+ & \beta_{10} \mathrm{POPULATION}+\beta_{11} \mathrm{SIZE}+\text { YEAR_FIXED_EFFECTS }+\varepsilon
\end{aligned}
$$

Our variable of interest VAIC is the intellectual capital efficiency for a given bank in a given year. In Equations (1) and (2), the independent variables UNCAP and FNMR separately capture the banks' organizational memory of specific bad times and the macroeconomic bad times. Consistent with our first two hypotheses, we expect to observe a significantly negative coefficient $\beta_{1}$ in Equation (1) and an insignificant coefficient $\beta_{1}$ in Equation (2). In Equations (3) and (4), the dependent variable ZSCORENEG and ALLP are the proxies for the bank risk taking and accounting conservatism separately for each bank in each year. Consistent with our third and fifth hypotheses, we predict that the coefficient $\beta_{1}$ in Equation (3) will be significantly negative and we expect to observe a significantly positive coefficient $\beta_{1}$ in Equation (4). In Equation (5), wholesale deposit ratio (WD) is defined as the wholesale deposits divided by total assets held by a given bank in each year. We expect to get a positive and significant coefficient on VAIC in Equation (5).

In Equations (3)-(5), we follow prior studies (e.g., Meles et al., 2016) to include variables that are specific to the banking industry: TIER1 (ratio of Tier 1 capital to risk-weighted assets), ROA (ratio of net income to total assets), LIQUIDITY (ratio of cash to total assets), NPL (ratio of nonperforming loans to total loans), CI (loan portfolio characteristics that are the proportions of commercial and industrial loans in a bank's total loans) and LOANS/DEP (ratio of total loans to total deposits). We include several variables to control for the effects of local demographic and economic conditions on banks' financial systems, as well as the size of the bank (SIZE). The economic indicators include UNEMPLOYMENT (state unemployment rate), POPULATION (county population size), and GDPPC (state GDP per capita levels). We include year-fixed effects to absorb unobservable variation common to all banks in a given year.

\section{Empirical Results}

Our sample for the empirical tests of intellectual capital efficiency comprises 
106,272 bank-year observations after deleting those that lack the data required to calculate the required variables. Table 1 provides descriptive statistics for the variables in the baseline models. The main variable of interest is the measure of intellectual capital efficiency, VAIC. We find that the mean value for VAIC is 2.197, consistent with prior literature (e.g., Meles et al., 2016). The mean of negative values of $\mathrm{Z}$ score (ZSCORENEG) is -3.288 , which is consistent with previous studies (e.g., Jin et al., 2013). The mean percentage of wholesale deposits (WD) is $31.0 \%$. In terms of control variables, the average Tier 1 capital ratio is $10.1 \%$ in our sampled commercial banks; the average ROA ratio is $0.8 \%$, indicating that the banks in our sample are marginally profitable; and the mean value of the natural logarithm of total assets (SIZE) is 11.955, which is very close to the mean value of SIZE $(11,807)$ reported by Liu $(2017)$.

Table 2 tabulates the Pearson correlation matrix for the variables in our regression models. We find a significant and negative correlation of -0.066 between VAIC and UNCAP. This result is consistent with our hypothesis that banks that have survived periods of undercapitalization tend to decrease their investment in intellectual capital. Therefore, these banks are more likely to exhibit a subsequent decrease in intellectual capital efficiency. Moreover, consistent with our hypotheses, the univariate results show that VAIC is negatively associated with ZSCORENEG and positively associated with ALLP at the $1 \%$ level.

According to our first hypothesis, we predict that banks that survived undercapitalized periods would invest less in intellectual capital and decrease the value that intellectual capital added to banks (i.e., intellectual capital efficiency). Table 3 presents the results of regression analysis on banks' institutional memory.

Table 1. Descriptive statistics for variables in the main tests (Full sample: 2000-2017).

\begin{tabular}{ccccccc}
\hline & $\mathrm{N}$ & Mean & Median & $\mathrm{Q} 1$ & $\mathrm{Q} 3$ & Standard Deviation \\
\hline VAIC & 106,272 & 2.197 & 2.211 & 1.728 & 2.708 & 1.356 \\
ZSCORENEG & 106,272 & -3.288 & -3.303 & -3.950 & -2.673 & 1.090 \\
ALLP & 106,272 & 1.031 & 0.267 & 0.075 & 0.678 & 3.258 \\
WD & 106,272 & 0.203 & 0.188 & 0.127 & 0.262 & 0.107 \\
TIER & 106,272 & 0.101 & 0.094 & 0.081 & 0.112 & 0.030 \\
ROA & 106,272 & 0.008 & 0.008 & 0.005 & 0.012 & 0.009 \\
LIQUIDITY & 106,272 & 0.066 & 0.044 & 0.028 & 0.079 & 0.061 \\
NPL & 106,272 & 0.016 & 0.008 & 0.003 & 0.019 & 0.022 \\
CI & 106,272 & 0.139 & 0.121 & 0.073 & 0.184 & 0.094 \\
LOANS/DEP & 106,272 & 0.776 & 0.787 & 0.650 & 0.909 & 0.198 \\
SIZE & 106,272 & 11.955 & 11.843 & 11.118 & 12.656 & 1.236 \\
GDPPC & 106,272 & 10.779 & 10.779 & 10.684 & 10.890 & 0.151 \\
UNEMPLOYMENT & 106,272 & 5.856 & 5.300 & 4.200 & 7.000 & 2.335 \\
POPULATION & 106,272 & 11.199 & 10.816 & 9.910 & 12.457 & 1.741 \\
\hline
\end{tabular}

Variables are defined in Appendix. 
Table 2. Pearson correlations for variables in the main tests.

\begin{tabular}{|c|c|c|c|c|c|c|c|c|c|c|c|c|c|c|c|c|}
\hline & Variable & 1 & 2 & 3 & 4 & 5 & 6 & 7 & 8 & 9 & 10 & 11 & 12 & 13 & 14 & 15 \\
\hline 1 & $V A I C$ & 1.000 & & & & & & & & & & & & & & \\
\hline 2 & $U N C A P$ & -0.066 & 1.000 & & & & & & & & & & & & & \\
\hline 3 & ZSCORENEG & -0.148 & 0.191 & 1.000 & & & & & & & & & & & & \\
\hline 4 & $A L L P$ & 0.014 & 0.033 & 0.039 & 1.000 & & & & & & & & & & & \\
\hline 5 & $W D$ & 0.029 & 0.101 & 0.143 & 0.027 & 1.000 & & & & & & & & & & \\
\hline 6 & $T I E R 1$ & 0.132 & -0.522 & -0.248 & -0.018 & -0.133 & 1.000 & & & & & & & & & \\
\hline 7 & $R O A$ & 0.564 & -0.177 & -0.317 & -0.005 & -0.089 & 0.143 & 1.000 & & & & & & & & \\
\hline 8 & LIQUIDITY & -0.119 & -0.044 & 0.046 & -0.029 & -0.190 & 0.094 & -0.138 & 1.000 & & & & & & & \\
\hline 9 & $N P L$ & -0.277 & 0.028 & 0.256 & -0.158 & 0.090 & 0.011 & -0.511 & 0.132 & 1.000 & & & & & & \\
\hline 10 & $C I$ & 0.0002 & 0.051 & 0.074 & 0.053 & 0.009 & -0.092 & 0.020 & -0.002 & -0.032 & 1.000 & & & & & \\
\hline 11 & $L O A N S / D E P$ & 0.031 & 0.027 & 0.100 & 0.024 & 0.424 & -0.091 & 0.011 & -0.287 & -0.029 & -0.015 & 1.000 & & & & \\
\hline 12 & SIZE & 0.136 & 0.099 & 0.031 & -0.029 & 0.228 & -0.191 & 0.058 & -0.178 & -0.009 & -0.002 & 0.266 & 1.000 & & & \\
\hline 13 & $G D P P C$ & -0.012 & -0.024 & 0.030 & -0.007 & -0.062 & 0.0008 & -0.025 & 0.088 & -0.037 & -0.035 & 0.032 & 0.138 & 1.000 & & \\
\hline 14 & UNEMPLOYMENT & -0.159 & -0.031 & 0.085 & -0.065 & 0.081 & 0.011 & -0.249 & 0.132 & 0.306 & -0.075 & -0.078 & 0.069 & -0.137 & 1.000 & \\
\hline 15 & POPULATION & -0.064 & 0.084 & 0.289 & 0.036 & 0.185 & -0.079 & -0.184 & -0.010 & 0.086 & 0.056 & 0.243 & 0.427 & 0.230 & 0.078 & 1.000 \\
\hline
\end{tabular}

Variables are defined in the Appendix. Continuous variables are winsorized at top and bottom 1\%. Bold numbers are significant at the $1 \%$ and $5 \%$ level, based on a two-tailed test.

Table 3. The effect of banks' organizational memory on intellectual capital efficiency.

\begin{tabular}{|c|c|c|c|c|}
\hline & $\begin{array}{c}\text { Bank-Specific } \\
\text { Bad Times } \\
\text { (Bank-Year Level) }\end{array}$ & $\begin{array}{c}\text { Bank-Specific } \\
\text { Bad Times } \\
\text { (Bank-Year Level) }\end{array}$ & $\begin{array}{c}\text { Macroeconomic } \\
\text { Bad Times } \\
\text { (Bank-Year Level) }\end{array}$ & $\begin{array}{c}\text { Macroeconomic } \\
\text { Bad Times } \\
\text { (Bank-Year Level) }\end{array}$ \\
\hline Variable & Dependent Var. $=$ VAIC & Dependent Var. $=$ VAIC & Dependent Var. $=$ VAIC & Dependent Var. $=$ VAIC \\
\hline Intercept & $\begin{array}{l}2.244^{* * *} \\
(156.99)\end{array}$ & $\begin{array}{l}-1.249 \\
(-1.42)\end{array}$ & $\begin{array}{l}2.193^{* * *} \\
(138.14)\end{array}$ & $\begin{array}{l}-0.753 \\
(-0.83)\end{array}$ \\
\hline$U N C A P$ & $\begin{array}{c}-0.220^{\star * *} \\
(-10.39)\end{array}$ & $\begin{array}{c}-0.363^{* * *} \\
(-15.46)\end{array}$ & & \\
\hline$F N M R$ & & & $\begin{array}{l}0.0002 \\
(0.59)\end{array}$ & $\begin{array}{l}0.0001 \\
(0.33)\end{array}$ \\
\hline SIZE & & $\begin{array}{c}0.278^{* * *} \\
(17.53)\end{array}$ & & $\begin{array}{c}0.261^{\star * *} \\
(16.80)\end{array}$ \\
\hline$G D P P C$ & & $\begin{array}{l}0.147 \\
(1.64)\end{array}$ & & $\begin{array}{l}0.121 \\
(1.31)\end{array}$ \\
\hline UNEMPLOYMENT & & $\begin{array}{c}-0.055^{\star * *} \\
(-7.77)\end{array}$ & & $\begin{array}{c}-0.053^{* * *} \\
(-7.44)\end{array}$ \\
\hline POPULATION & & $\begin{array}{c}-0.116^{* * *} \\
(-12.47)\end{array}$ & & $\begin{array}{c}-0.118^{* * *} \\
(-12.89)\end{array}$ \\
\hline YEAR FIXED EFFECTS & YES & YES & YES & YES \\
\hline Adj. $R^{2}$ & 0.0044 & 0.1083 & 0.00002 & 0.0971 \\
\hline \# of Observations & 106,272 & 106,272 & 106,272 & 106,272 \\
\hline
\end{tabular}

Table 3 reports the results for the regression models with standard errors clustered by counties. The dependent variable VAIC is defined as Value-Added Intellectual Coefficient. The proxy for bank-specific bad times, UNCAP, is an indicator variable which equals to 1 when the tier 1 risk-based capital ratio is under $4 \%$ (before 1990) or the total risk-based ratio is under $8 \%$ (after 1990), 0 otherwise. The proxy for the macroeconomic bad times, FNMR, is the average proportion of banks failed in the state in a given year. We use the Quarterly Report of Condition and Income (Call Reports) obtained from the Federal Financial Institutions (FEEIC) (https://cdr.ffiec.gov/public/). We winsorize the top and bottom $1 \%$ of all the continuous variables. ${ }^{*},{ }^{* *},{ }^{* * *}$ indicate significance at the $10 \%, 5 \%$, and $1 \%$ levels, respectively, based on a two-tailed test. Variables are defined in Appendix. 
Column 2 presents the multivariate regression results for testing the hypothesized relationship using Equation (1). We find that the coefficient of UNCAP is negative at the $1 \%$ significance level $(\mathrm{t}$-statistic $=-15.46)$, consistent with $\mathrm{H} 1$ that intellectual capital efficiency decreases following the bank-specific experience of undercapitalization. As predicted, the estimated coefficient of FNMR is not significant $(t-s t a t i s t i c=0.33)$. This result supports the second hypothesis, which argues that there is no causal relationship between a bank's observation of other banks' failure and its subsequent intellectual capital efficiency.

Table 4 presents the results of regression analysis on banks' risk-taking behavior. Columns 1 and 2 present the univariate and multivariate regression results with negative $Z$ score (ZSCORENEG) as the dependent variable, respectively. Our estimated coefficients of VAIC indicate that banks with greater intellectual capital efficiency take fewer risks. Column 2 shows that the coefficient on VAIC is negative and significant at $1 \%$ level $(\mathrm{t}$-statistic $=-3.06)$. These results confirm our hypothesis regarding the relationship between bank risk-taking behaviors and intellectual capital efficiency.

Regarding the control variables in the baseline models, we find that most of the estimated coefficients are consistent with our prediction. The Tier 1 capital ratio (TIER1) is negatively associated with the ZSCORENEG at the $1 \%$ level $(\mathrm{t}$-statistic $=-22.03)$. The coefficient on nonperforming loans $(\mathrm{NPL})$ is positive and significant at the $1 \%$ level $(\mathrm{t}$-statistic $=33.40)$. The nonperforming loans ratio can be interpreted as an indicator variable of credit risk in banks (Lotto, 2018). Thus, these results confirm our expectation that banks' capital structure and credit risk management affect their risk-taking incentives and behaviors. In addition, we find that the coefficient on liquidity (LIQUIDITY) is positive and significant at the $1 \%$ level $(\mathrm{t}$-statistic $=5.74)$. Moreover, the results from the control variables capturing macroeconomic indicators support our prediction that macroeconomic conditions (e.g., shocks and crisis) affect banks' risk-taking behavior. For example, the population size at the county level in the U.S. (POPULATION) is positively associated with ZSCORENEG at the $1 \%$ level $(\mathrm{t}$-statistic $=22.78)$.

Table 5 presents the results of regression analysis on banks' accounting conservatism. Column 1 and Column 2 present the univariate and multivariate regression results with discretionary loan loss provisions (ALLP) as the dependent variable, respectively. The estimated coefficients of VAIC tabulated in Column 1 and Column 2 confirm our prediction that banks with higher levels of intellectual capital efficiency exhibit more conservative behaviors and fewer earnings management behaviors. The coefficient of VAIC in Column 2 is positive and significant at $1 \%$ level $(\mathrm{t}$-statistic $=3.54)$ as expected.

The results of the regression analysis on the relationship between intellectual capital efficiency and banks' funding structure are tabulated in Table 6. Our hypothesis predicts that banks may attract more wholesale funding deposits when they have greater intellectual capital efficiency. In Column 2, the coefficient of VAIC is positive and significant at the $1 \%$ level $(\mathrm{t}$-statistic $=8.05)$. This 
Table 4. The effect of intellectual capital efficiency on banks' risk-taking behaviors.

\begin{tabular}{|c|c|c|}
\hline & $\begin{array}{c}\text { Baseline Model } \\
\text { (Bank-Year Level) }\end{array}$ & $\begin{array}{c}\text { Baseline Model } \\
\text { (Bank-Year Level) }\end{array}$ \\
\hline Variable & Dependent Var. $=$ ZSCORENEG & Dependent Var. $=$ ZSCORENEG \\
\hline Intercept & $\begin{array}{l}-3.016^{\star * *} \\
(-108.46)\end{array}$ & $\begin{array}{c}-2.254^{\star * *} \\
(-2.10)\end{array}$ \\
\hline VAIC & $\begin{array}{c}-0.122^{\star * *} \\
(-9.40)\end{array}$ & $\begin{array}{c}-0.025^{\star * *} \\
(-3.06)\end{array}$ \\
\hline TIER 1 & & $\begin{array}{l}-7.937^{\star * *} \\
(-22.03)\end{array}$ \\
\hline LIQUIDITY & & $\begin{array}{c}0.812^{\star * *} \\
(5.74)\end{array}$ \\
\hline$N P L$ & & $\begin{array}{c}10.626^{* * *} \\
(33.40)\end{array}$ \\
\hline$C I$ & & $\begin{array}{c}0.461^{\star * *} \\
(4.67)\end{array}$ \\
\hline$L O A N S / D E P$ & & $\begin{array}{c}0.306^{\star * *} \\
(7.74)\end{array}$ \\
\hline$S I Z E$ & & $\begin{array}{l}-0.113^{* * *} \\
(-11.09)\end{array}$ \\
\hline$G D P P C$ & & $\begin{array}{l}-0.145 \\
(-1.44)\end{array}$ \\
\hline UNEMPLOYMENT & & $\begin{array}{c}-0.027^{\star * *} \\
(-4.68)\end{array}$ \\
\hline POPULATION & & $\begin{array}{l}0.190^{* * *} \\
(22.78)\end{array}$ \\
\hline YEAR FIXED EFFECTS & YES & YES \\
\hline Adj. $R^{2}$ & 0.0221 & 0.2203 \\
\hline \# of Observations & 106,272 & 106,272 \\
\hline
\end{tabular}

Table 4 reports the results for the regression models with standard errors clustered by counties. The dependent variable ZSCORENEG is defined as the negative value of the return on assets plus capital asset ratio, divided by the standard deviation of return on assets. This variable is the negative values of ZSCORE. We use the Quarterly Report of Condition and Income (Call Reports) obtained from the Federal Financial Institutions (FEEIC) (https://cdr.ffiec.gov/public/). We winsorize the top and bottom $1 \%$ of all the continuous variables. ${ }^{*},{ }^{* * *}$ indicate significance at the $10 \%, 5 \%$, and $1 \%$ levels, respectively, based on a two-tailed test. Variables are defined in Appendix.

Table 5. The effect of intellectual capital efficiency on banks' accounting conservatism.

\begin{tabular}{ccc}
\hline & $\begin{array}{c}\text { Baseline Model } \\
\text { (Bank-Year Level) }\end{array}$ & $\begin{array}{c}\text { Baseline Model } \\
\text { (Bank-Year Level) }\end{array}$ \\
\hline Variable & Dependent Var. $=$ ALLP & Dependent Var. $=$ ALLP \\
Intercept & $0.953^{\star * *}$ & 1.788 \\
& $(33.54)$ & $(1.32)$ \\
VAIC & $0.035^{\star * *}$ & $0.045^{\star * *}$ \\
\end{tabular}




\section{Continued}

\begin{tabular}{|c|c|c|}
\hline TIER 1 & & $\begin{array}{l}0.760 \\
(1.17)\end{array}$ \\
\hline$R O A$ & & $\begin{array}{c}-37.142^{\star * *} \\
(-18.24)\end{array}$ \\
\hline LIQUIDITY & & $\begin{array}{l}0.257 \\
(1.06)\end{array}$ \\
\hline$N P L$ & & $\begin{array}{c}-29.880^{\star * *} \\
(-30.18)\end{array}$ \\
\hline$C I$ & & $\begin{array}{c}1.203^{* * *} \\
(6.82)\end{array}$ \\
\hline$L O A N S / D E P$ & & $\begin{array}{c}0.288^{* * *} \\
(2.66)\end{array}$ \\
\hline SIZE & & $\begin{array}{c}-0.080^{* * *} \\
(-5.36)\end{array}$ \\
\hline$G D P P C$ & & $\begin{array}{l}-0.076 \\
(-0.61)\end{array}$ \\
\hline UNEMPLOYMENT & & $\begin{array}{c}-0.049^{* * *} \\
(-6.29)\end{array}$ \\
\hline POPULATION & & $\begin{array}{c}0.095^{\star * *} \\
(6.33)\end{array}$ \\
\hline YEAR FIXED EFFECTS & YES & YES \\
\hline Adj. $R^{2}$ & 0.0002 & 0.0489 \\
\hline \# of Observations & 106,272 & 106,272 \\
\hline
\end{tabular}

Table 5 reports the results for the regression models with standard errors clustered by counties. The dependent variable ALLP is the ratio of the allowance of loan loss provisions divided by nonperforming loans. We use the Quarterly Report of Condition and Income (Call Reports) obtained from the Federal Financial Institutions (FEEIC) (https://cdr.ffiec.gov/public/). We winsorize the top and bottom $1 \%$ of all the continuous variables. ${ }^{*},{ }^{* *},{ }^{* *}$ indicate significance at the $10 \%, 5 \%$, and $1 \%$ levels, respectively, based on a two-tailed test. Variables are defined in Appendix.

Table 6. The effect of intellectual capital efficiency on banks' funding structure.

\begin{tabular}{ccc}
\hline & $\begin{array}{c}\text { Baseline Model } \\
\text { (Bank-Year Level) }\end{array}$ & $\begin{array}{c}\text { Baseline Model } \\
(\text { Bank-Year Level) }\end{array}$ \\
\hline Variable & Dependent Var. $=W D$ & Dependent Var. $=W D$ \\
Intercept & $0.198^{* * *}$ & $0.676^{* * *}$ \\
& $(81.64)$ & $(7.70)$ \\
VAIC & $0.002^{* * *}$ & $0.006^{* * *}$ \\
& $(2.61)$ & $(8.05)$ \\
TIER1 & & $-0.252^{* * *}$ \\
& & $(-7.18)$ \\
ROA & & $-1.008^{* * *}$ \\
& & $(-9.54)$ \\
LIQUIDITY & $-0.118^{* * *}$ \\
& & $(-8.35)$ \\
& & $0.270^{* * *}$ \\
& & $(6.74)$ \\
\hline
\end{tabular}




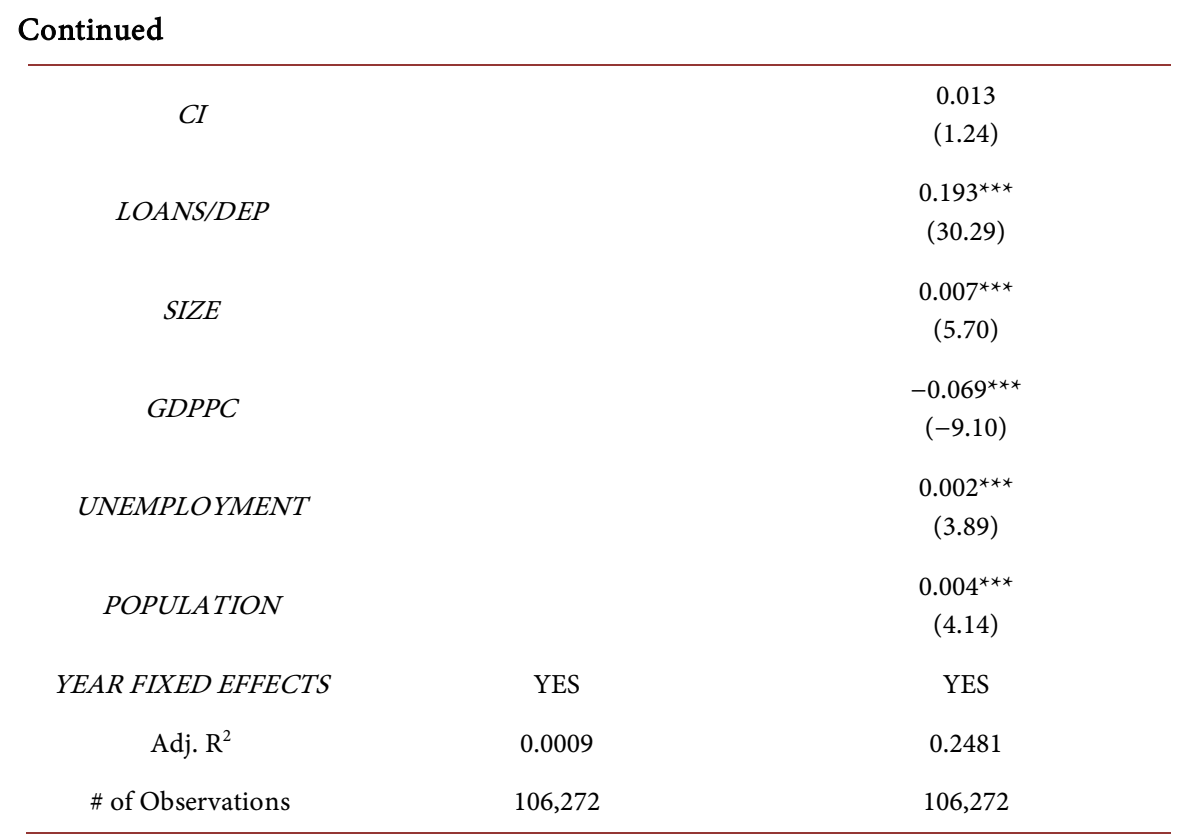

Table 6 reports the results for the regression models with standard errors clustered by counties. The dependent variable $\mathrm{WD}$ is wholesale deposits scaled by total assets. We winsorize the top and bottom $1 \%$ of all the continuous variables. ${ }^{*},{ }^{* *},{ }^{* *}$ indicate significance at the $10 \%, 5 \%$, and $1 \%$ levels, respectively, based on a two-tailed test. Variables are defined in Appendix.

result indicates that intellectual capital efficiency can enhance banks' ability to attract wholesale funding deposits.

We investigate the role of three subcomponents of intellectual capital (human, structural, and relational). We are motivated by previous studies to analyze these subcomponents. For example, Mojtahedi (2013) examines the effects of each on firms' earnings quality. Meles et al. (2016) test the distinct effects of the three sub-aggregates of value-added intellectual capital (HCE, RCE, and SCE) on firm performance. Using the same regression models, Sullivan and Sullivan (2000) get significantly positive coefficients on HCE and RCE and a negative coefficient on SCE when the dependent variable is firm profitability. Moreover, Wang (2016) finds that human capital not only has direct effects on financial performance, but also acts as a moderating variable in the causal connection between intellectual capital and firm performance. Based on these findings, Wang (2016) concludes that human capital is the core factor of intellectual capital. We conduct additional tests to measure the distinct effects of HCE, SCE, and RCE in determining banks' accounting conservatism. Following Mojtahedi (2013) and Meles et al. (2016), we specify the following Equation (6) by replacing VAIC in the baseline regression models (4) with HCE, SCE, and RCE.

$$
\begin{aligned}
\mathrm{ALLP}= & \beta_{0}+\beta_{1} \mathrm{HCE}+\beta_{2} \mathrm{SCE}+\beta_{3} \mathrm{RCE}+\beta_{4} \mathrm{TIER} 1+\beta_{5} \mathrm{ROA} \\
& +\beta_{6} \mathrm{LIQUIDITY}+\beta_{7} \mathrm{NPL}+\beta_{8} \mathrm{CI}+\beta_{9} \frac{\text { LOANS }}{\mathrm{DEP}}+\beta_{10} \mathrm{GDPPC} \\
& +\beta_{11} \mathrm{UNEMPLOYMENT}+\beta_{12} \mathrm{POPULATION} \\
& +\beta_{13} \mathrm{SIZE}+\text { YEAR_FIXED_EFFECTS }+\varepsilon
\end{aligned}
$$


Regression results are tabulated in Table 7. Our results are similar to those reported by Sullivan and Sullivan (2000) who find significant and positive relationships between two ingredients of capital efficiency (HCE and RCE) and firm profitability. However, they find the opposite result for the coefficient on SCE.

Table 7. The effect of subcomponents of intellectual capital efficiency.

\begin{tabular}{|c|c|}
\hline & $\begin{array}{c}\text { Baseline Model } \\
\text { (Bank-Year Level) }\end{array}$ \\
\hline Variable & Dependent Var. $=A L L P$ \\
\hline Intercept & $\begin{array}{l}1.719 \\
(1.26)\end{array}$ \\
\hline$H C E$ & $\begin{array}{c}0.001^{\star *} \\
(2.20)\end{array}$ \\
\hline$S C E$ & $\begin{array}{c}-0.00001 \\
(-0.12)\end{array}$ \\
\hline$R C E$ & $\begin{array}{c}0.888^{* *} \\
(2.51)\end{array}$ \\
\hline TIER 1 & $\begin{array}{l}0.814 \\
(1.24)\end{array}$ \\
\hline$R O A$ & $\begin{array}{c}-35.186^{\star * *} \\
(-17.99)\end{array}$ \\
\hline LIQUIDITY & $\begin{array}{l}0.241 \\
(1.00)\end{array}$ \\
\hline$N P L$ & $\begin{array}{c}-29.872^{* * *} \\
(-29.98)\end{array}$ \\
\hline$C I$ & $\begin{array}{c}1.192^{* * *} \\
(6.75)\end{array}$ \\
\hline$L O A N S / D E P$ & $\begin{array}{c}0.282^{* * *} \\
(2.60)\end{array}$ \\
\hline$S I Z E$ & $\begin{array}{c}-0.073^{\star * *} \\
(-4.67)\end{array}$ \\
\hline$G D P P C$ & $\begin{array}{l}-0.069 \\
(-0.56)\end{array}$ \\
\hline UNEMPLOYMENT & $\begin{array}{c}-0.050^{* * *} \\
(-6.32)\end{array}$ \\
\hline POPULATION & $\begin{array}{l}0.093^{* * *} \\
(6.28)\end{array}$ \\
\hline YEAR FIXED EFFECTS & YES \\
\hline Adj. $R^{2}$ & 0.0487 \\
\hline \# of Observations & 106,272 \\
\hline
\end{tabular}

Table 7 reports the results for the regression models with standard errors clustered by counties. The interested independent variables HCE, SCE and RCE represent subcomponents of intellectual capital efficiency: human capital efficiency, structural capital efficiency and relational capital efficiency. We winsorize the top and bottom $1 \%$ of all the continuous variables. ${ }^{*}, * *, * *$ indicate significance at the $10 \%, 5 \%$, and $1 \%$ levels, respectively, based on a two-tailed test. Variables are defined in Appendix. 
Similarly, we find that both HCE and RCE have positive correlations with banks' accounting conservatism and that the coefficients of HCE and RCE are significant at the $5 \%$ level ( $\mathrm{t}$-value $=2.20$ and 25.1 respectively). We fail to find a significant coefficient for SCE ( $\mathrm{t}$-value $=-0.12)$. Therefore, we conclude that human capital efficiency and relational capital efficiency affect accounting conservatism in the banking sector.

We continue to investigate whether our testable hypotheses about bank risk-taking behaviors and accounting conservatism are valid for both public and private banks. To detect the moderating effects of banks' listing status, we add an interaction term PUBLIC * VAIC into our baseline empirical regression models, where PUBLIC is a dummy variable set at 1 if the bank is listed in a stock exchange, and 0 otherwise. Our untabulated results show that when the dependent variables are ZSCORENEG and ALLP, the coefficients of the interaction term PUBLIC * VAIC are not significant, with $t$-values of -1.44 and -0.66 , respectively. Taken together, our results show that the influence of intellectual capital efficiency on banks' risk-taking behavior and accounting conservatism is not different between public and private banks.

\section{Conclusion}

By investigating the determinants and consequences of intellectual capital efficiency in the U.S. banking industry, we complement the literature on intellectual capital research by determining that intellectual capital efficiency provides immense value to commercial banks. We have four findings from our empirical analysis. First, banks' individual institutional memory of bad times would reduce intellectual capital efficiency in the subsequent periods, and banks' experience of macroeconomic shocks would not significantly change their intellectual capital efficiency. Second, intellectual capital efficiency restricts banks' risk-taking behaviors and enhances their accounting conservatism. Third, intellectual capital efficiency helps banks attract more wholesale funding deposits. Fourth, we test the impact of three components of the VAIC variable on bank accounting conservatism and find that human capital efficiency and relational capital efficiency have a significant impact on bank accounting conservatism.

Our findings have a significant impact on the operating efficiency and profits of commercial banks. Banks' individual memory of their own bad times will decrease the bank employees' skills, productivity, and efficiency and reduce the social trust between banks and customers. The higher bank employees' skills, productivity, and work efficiency, the fewer incentives for bank managers to conduct risky projects and do earnings management. The improved bank employees' skills, productivity, and work efficiency are viewed as positive signals by the wholesale depositors, and as a result, the wholesale depositors are more likely to invest in these banks. Our results point out a right path for bank managers. On the one hand, bank managers should take projects with low or medium risks in order to improve their employees' skills, productivity, and work efficiency. On 
the other hand, the high level of bank employees' skills, productivity, and work efficiency can effectively increase the social trust of wholesale customers and receive more wholesale deposits.

Our paper contributes to the literature by extending the research on intellectual capital efficiency. Prior studies have explored the research questions on organizational behaviors. A few studies in accounting research have investigated earnings management issues in nonfinancial industries. We show that, in addition to earnings management, intellectual capital efficiency can significantly affect banks' risk-taking behaviors, accounting conservatism, and funding structure. We also show that institutional memory is a determinant of intellectual capital efficiency. Therefore, our findings indicate that regulators should put more emphasis on banks' disclosure of intellectual capital when they create more efficient regulations in the banking sector.

In order to study this topic better in the future, we discuss the shortcomings of the paper. We currently use the accounting variables to measure the bank employees' intellectual capital efficiency and its three components, human capital efficiency, relational capital efficiency, and structural capital efficiency. In order to accurately measure the level of bank employees' skills, productivity, and work efficiency, we need to independently examine the banks' employees' skills, productivity, and work efficiency. For instance, we can independently survey and interview bank managers regarding their employee's skills, productivity, and work efficiency. These survey and interview data will help us understand the bank employees' intellectual capital efficiency better.

\section{Conflicts of Interest}

The authors declare no conflicts of interest regarding the publication of this paper.

\section{References}

Abdulaali, A. R. (2018). The Impact of Intellectual Capital on Business Organization. Academy of Accounting and Financial Studies Journal, 22, 1-16.

Aebi, V., Sabato, G., \& Schmid, M. (2012). Risk Management, Corporate Governance, and Bank Performance in the Financial Crisis. Journal of Banking \& Finance, 36, 3213-3226. https://doi.org/10.1016/j.jbankfin.2011.10.020

Basu, S. (1997). The Conservatism Principle and the Asymmetric Timeliness of Earnings. Journal of Accounting and Economics, 24, 3-37. https://doi.org/10.1016/S0165-4101(97)00014-1

Beatty, A., \& Liao, S. (2011). Do Delays in Expected Loss Recognition Affect Banks' Willingness to Lend? Journal of Accounting and Economics, 52, 1-20. https://doi.org/10.1016/j.jacceco.2011.02.002

Belias, D. (2014). Organizational Culture and Job Satisfaction, in Banking Sector-A Review. International Journal of Human Resources Management, 3, 1-20.

Bouwman, C. H., \& Malmendier, U. (2015). Does a Bank's History Affect Its Risk-Taking? American Economic Review, 105, 321-325. 
https://doi.org/10.1257/aer.p20151093

Bushman, R. M., \& Williams, C. D. (2012). Accounting Discretion, Loan Loss Provisioning, and Discipline of Banks' Risk-Taking. Journal of Accounting and Economics, 54, 1-18. https://doi.org/10.1016/j.jacceco.2012.04.002

Bushman, R. M., Davidson, R. H., Dey, A., \& Smith, A. (2015). Bank CEO Materialism, Corporate Culture and Risk. Georgetown University McDonough School of Business Research Papers Series, 2780088.

Dahl, D., \& Spivey, M. F. (1995). Prompt Corrective Action and Bank Efforts to Recover from Undercapitalization. Journal of Banking \& Finance, 19, 225-243. https://doi.org/10.1016/0378-4266(94)00055-8

Darabi, R., Rad, S. K., \& Ghadiri, M. (2012). The Relationship between Intellectual Capital and Earnings Quality. Research Journal of Applied Sciences, Engineering and Technology, 4, 4192-4199.

Daum, J. H. (2003). Intangible Assets and Value Creation. New York: John Wiley \& Sons.

Federal Deposit Insurance Corporation (FDIC) (1992). Memorandum on Prompt Corrective Action (Oct).

Financial Stability Board (2014). Guidance on Supervisory Interaction with Financial Institutions on Risk Culture: A Framework for Assessing Risk Culture. Basel: Financial Stability Board.

Garrett, J., Hoitash, R., \& Prawitt, D. F. (2014). Trust and Financial Reporting Quality. Journal of Accounting Research, 52, 1087-1125. https://doi.org/10.1111/1475-679X.12063

Givoly, D., Hayn, C. K., \& Katz, S. P. (2010). Does Public Ownership of Equity Improve Earnings Quality? The Accounting Review, 85, 195-225. https://doi.org/10.2308/accr.2010.85.1.195

Gogan, L. M., Artene, A., Sarca, I., \& Draghici, A. (2016). The Impact of Intellectual Capital on Organizational Performance. Procedia-Social and Behavioral Sciences, 221, 194-202. https://doi.org/10.1016/j.sbspro.2016.05.106

Haris, M., Yao, H., Tariq, G., Malik, A., \& Javaid, H. M. (2019). Intellectual Capital Performance and Profitability of Banks: Evidence from Pakistan. Journal of Risk and Financial Management, 12, 56. https://doi.org/10.3390/jrfm12020056

Jin, J. Y., Kanagaretnam, K., Lobo, G. J., \& Mathieu, R. (2013). Impact of FDICIA Internal Controls on Bank Risk Taking. Journal of Banking \& Finance, 37, 614-624. https://doi.org/10.1016/j.jbankfin.2012.09.013

Jin, J. Y., Kanagaretnam, K., Lobo, G. J., \& Mathieu, R. (2017). Social Capital and Bank Stability. Journal of Financial Stability, 32, 99-114. https://doi.org/10.1016/j.jfs.2017.08.001

Jones, T. M. (1991). Ethical Decision Making by Individuals in Organizations: An Issue-Contingent Model. Academy of Management Review, 16, 366-395. https://doi.org/10.5465/amr.1991.4278958

Jordão, R. V. D., \& Almeida, V. R. D. (2017). Performance Measurement, Intellectual Capital and Financial Sustainability. Journal of Intellectual Capital, 18, 643-666. https://doi.org/10.1108/JIC-11-2016-0115

Kanagaretnam, K., Lim, C. Y., \& Lobo, G. J. (2013). Influence of National Culture on Accounting Conservatism and Risk-Taking in the Banking Industry. The Accounting Review, 89, 1115-1149. https://doi.org/10.2308/accr-50682

Kanagaretnam, K., Lim, C., \& Lobo, G. (2011). Effects of National Culture on Bank Risk Taking. Journal of International Business Studies, 42, 853-874. 
https://doi.org/10.1057/jibs.2011.26

Kariuki, A., \& Kiambati, K. (2017). Intellectual Capital, Corporate Culture and Performance of Firms Listed on Nairobi Securities Exchange.

Kravet, T. D. (2014). Accounting Conservatism and Managerial Risk-Taking: Corporate Acquisitions. Journal of Accounting and Economics, 57, 218-240. https://doi.org/10.1016/j.jacceco.2014.04.003

Kujansivu, P., \& Lönnqvist, A. (2007). Investigating the Value and Efficiency of Intellectual Capital. Journal of Intellectual Capital, 8, 272-287. https://doi.org/10.1108/14691930710742844

Lara, J. M. G., Osma, B. G., \& Penalva, F. (2016). Accounting Conservatism and Firm Investment Efficiency. Journal of Accounting and Economics, 61, 221-238. https://doi.org/10.1016/j.jacceco.2015.07.003

Levitt, B., \& March, J. G. (1988). Organizational Learning. Annual Review of Sociology, 14, 319-338. https://doi.org/10.1146/annurev.so.14.080188.001535

Li, K., Griffin, D., Yue, H., \& Zhao, L. (2013). How Does Culture Influence Corporate Risk-Taking? Journal of Corporate Finance, 23, 1-22. https://doi.org/10.1016/j.jcorpfin.2013.07.008

Li, X., Tripe, D. W., \& Malone, C. B. (2017). Measuring Bank Risk: An Exploration of Z-Score. https://doi.org/10.2139/ssrn.2823946

Liu, Y. (2017). Three Essays in Bank Financial Reporting. Doctoral Dissertation, Ontario: McMaster University.

Lotto, J. (2018). The Empirical Analysis of the Impact of Bank Capital Regulations on Operating Efficiency. International Journal of Financial Studies, 6, 34. https://doi.org/10.3390/ijfs6020034

Mechelli, A., \& Cimini, R. (2017). Accounting Conservatism and Risk Culture. In Risk Culture in Banking (pp. 387-401). Cham: Palgrave Macmillan. https://doi.org/10.1007/978-3-319-57592-6_17

Meles, A., Porzio, C., Sampagnaro, G., \& Verdoliva, V. (2016). The Impact of the Intellectual Capital Efficiency on Commercial Banks Performance: Evidence from the US. Journal of Multinational Financial Management, 36, 64-74. https://doi.org/10.1016/j.mulfin.2016.04.003

Mojtahedi, P. (2013). The Impact of Intellectual Capital on Earning Quality: Evidence from Malaysian Firms. Australian Journal of Basic and Applied Sciences, 7, 535-540.

Nahapiet, J., \& Ghoshal, S. (1998). Social Capital, Intellectual Capital, and the Organizational Advantage. Academy of Management Review, 23, 242-266. https://doi.org/10.5465/amr.1998.533225

Nicoletti, A. (2018). The Effects of Bank Regulators and External Auditors on Loan Loss Provisions. Journal of Accounting and Economics, 66, 244-265.

Putnam, R. D. (1995). Tuning in, Tuning out: The Strange Disappearance of Social Capital in America. PS: Political Science \& Politics, 28, 664-683. https://doi.org/10.1017/S1049096500058856

Roy, A. D. (1952). Safety First and the Holding of Assets. Econometrica: Journal of the Econometric Society, 20, 431-449. https://doi.org/10.2307/1907413

Stewart, T., \& Ruckdeschel, C. (1998). Intellectual Capital: The New Wealth of Organizations. Performance Improvement, 37, 56-59. https://doi.org/10.1002/pfi.4140370713

Still, K., Huhtamäki, J., \& Russell, M. (2013). Relational Capital and Social Capital: One or Two Fields of Research? In Proceedings of the 10th International Conference on Intel- 
lectual Capital, Knowledge Management and Organisational Learning: ICICKM 2013 (pp. 420). Washington DC: Academic Conferences Limited.

Sullivan Jr., P. H., \& Sullivan Sr., P. H. (2000). Valuing Intangibles Companies: An Intellectual Capital Approach. Journal of Intellectual Capital, 1, 328-340. https://doi.org/10.1108/14691930010359234

Tan, Y. (2016). The Impacts of Risk and Competition on Bank Profitability in China. Journal of International Financial Markets, Institutions and Money, 40, 85-110. https://doi.org/10.1016/j.intfin.2015.09.003

Thakor, A. V. (2015). Corporate Culture in Banking. https://doi.org/10.2139/ssrn.2565514

Truno, M., Stolyarov, A., Auger, D., \& Assaf, M. (2017). Wholesale Funding of the Big Six Canadian Banks. Bank of Canada Review, 2017, 42-55.

Wang, H. (2016). A Study on Corporate Culture, Intellectual Capital and Corporate Performance. International Journal of Simulation-Systems, Science \& Technology, 17, 1-4. https://doi.org/10.5296/rae.v8i1.8675

Yang, C. C., \& Lin, C. Y. Y. (2009). Does Intellectual Capital Mediate the Relationship between HRM and Organizational Performance? Perspective of a Healthcare Industry in Taiwan. The International Journal of Human Resource Management, 20, 1965-1984.

Yen, S. B., Lee, C. A., \& Arokiasamy, L. (2019). Review of Empirical Research on Intellectual Capital and Financial Performance in the Banking Sector. Global Business \& Management Research, 11, No. 1. 


\section{Appendix: Variable Definitions and Descriptions}

\section{Variables}

Main Variables of Interest:

VAIC

HCE

$R C E$

$S C E$

$S C$

$V A$

$C A$

UNCAP

FNMR

ZSCORE

ZSCORENEG

$A L L P$

$W D$

Firm-Level Bank-Specific Controls:

TIER 1

$R O A$

LIQUIDITY

$N P L$

CI

LOANS/DEP

SIZE

Macroeconomic Controls:
Description

VA (Value Added) is defined as the profit before income tax and extraordinary items and other adjustments plus the total salaries and employee benefits: RIAD4301 + RIAD4135. CA is the book value of assets in a firm.

$\mathrm{VAIC}=\mathrm{HCE}+\mathrm{RCE}+\mathrm{SCE}$.

This variable is the human capital efficiency component of VAIC which is calculated based on the overall payroll expenses: RIAD4135.

$\mathrm{HCE}=\mathrm{VA} / \mathrm{HC}$.

This variable is the relational capital efficiency component of VAIC.

$\mathrm{RCE}=\mathrm{VA} / \mathrm{CA}$.

This variable is the structural capital efficiency component of VAIC.

SCE $=$ SC/VA.

This variable is the structure capital component of intellectual capital.

$\mathrm{SC}=\mathrm{VA}-\mathrm{HC}$.

This variable is the difference between a firm's total output and total input.

This variable is the book value of both physical and financial net assets in an organization.

This variable equals to 1 when the tier 1 risk-based capital ratio is under $4 \%$ (before 1990) or the total risk-based ratio is under $8 \%$ (after 1990), 0 otherwise.

This variable is the average proportion of banks failed in the state in a given year.

This variable is defined as the return on assets plus capital asset ratio, divided by the standard deviation of return on assets.

This variable is the negative values of ZSCORE.

This variable is the ratio of the allowance of loan loss provisions divided by nonperforming loans.

This variable is wholesale funds scaled by total assets. Wholesale funds are calculated by subtracting core deposits from total liabilities where core deposits are the sum of transaction deposits, saving deposits, and time deposits less than \$100,000: RCON2215 + RCON6810 + RCON0352 + RCON6648.

This variable is the ratio of Tier 1 capital to total risk-weighted assets.

This variable is the ratio of net income to total assets.

This variable is the ratio of cash to total assets.

This variable is the ratio of nonperforming loans to total loans.

This variable is the ratio of commercial and industrial loans to total loans.

This variable is the ratio of total loans to total deposits.

This variable is the natural logarithm of total assets.

This variable is the natural logarithm of the levels of gross domestic products per capita by state. Data source: The national income and product accounts can be obtained from the Economic Research Federal Reserve Bank of St. Louis website at: https://research.stlouisfed.org/. 


\section{Continued}

UNEMPLOYMENT

POPULATION
This variable is the unemployment rate by state.

Data source: The local area unemployment statistics can be obtained from the U.S.

Bureau of Labor Statistics website at: https://www.bls.gov/lau/.

This variable is the natural logarithm of the population size by county.

Data source: The population and housing unit estimates can be obtained from the United States Census Bureau website at: https://www.census.gov/programs-surveys/popest/data/data-sets.html. 